\title{
New Light on Dr Thomas Moffet: The Triple Roles of an Early Modern Physician, Client, and Patronage Broker
}

\author{
FRANCES DAWBARN*
}

\begin{abstract}
Introduction
Thomas Moffet (1553-1604) has been the subject of many studies. In particular, Virgil Heltzel and Hoyt Hudson, C E Raven, Hugh Trevor-Roper, Margaret Pelling, Charles Webster, Allen Debus, and Victor Houliston have contributed importantly to our understanding of the life, career, and works of one of England's earliest, and most significant, Paracelsians. ${ }^{1}$ Through their work, we have come to know Moffet as etymologist, Paracelsian physician, author, member of the London College of Physicians, and physician and biographer of Sir Philip Sidney. This paper examines certain important aspects of his career in closer detail, and considers Moffet's intricate and interrelated "triple roles" as a member of the College of Physicians, a client of Robert Devereux, second Earl of Essex, and as a patronage broker to those who sought preferment within his circle; in so doing, it draws upon the indispensable work already done.

Importantly, new light on Thomas Moffet may be said to radiate largely from the multi-faceted nature of patronage, and patronage relationships, in a highly transitional time in the history of English medicine. Through the agency of patronage, the heterodox cures of some physicians were legitimized, boundaries between Galenic physician and surgeon/empiric began to be eroded, and the social advancement of marginalized medical providers was fostered and encouraged. As a practising physician and an active and controversial natural philosopher, Thomas Moffet was not
\end{abstract}

\footnotetext{
* Frances Dawbarn, PhD, Honorary Research Fellow in History, Lancaster University, Furness College, Lancaster LA1 4YG.
}

I should like to thank Stephen Pumfrey, Deborah Powell, and Tom Dixon for their help and advice during the writing of this paper. Some of the material used in this paper appears in F Dawbarn, 'Patronage and power: the College of Physicians and the Jacobean Court', Br. J. Hist. Sci., 1998, 31: 1-19.

\footnotetext{
${ }^{1}$ Thomas Moffet, Nobilis: or, a view of the life and death of a Sidney, and Lessus lugubris, 1592, transl. Virgil B Heltzel and Hoyt H Hudson, San Marino, CA, The Huntingdon Library, 1940; C E Raven, English naturalists from Neckam to Ray: a study in the making of the modern world,
}

Cambridge University Press, 1947; Hugh TrevorRoper, 'The Paracelsian movement', in Hugh Trevor-Roper (ed.), Renaissance essays, London, Secker and Warburg, 1985, pp. 149-99; Margaret Pelling and Charles Webster, 'Medical practitioners', in C Webster (ed.), Health, medicine and mortality in the sixteenth century, Cambridge University Press, 1979, pp. 165-235; Charles Webster, 'Alchemical practitioners', ibid., pp. 301-34; Allen Debus, The English Paracelsians, New York, Franklin Watts, 1966; V H Houliston, 'A critical edition, with an introduction and notes, of the English works of Thomas Moffet, M.D. (1553-1604): The Silkewormes and their flies (1599) and Healths improvement (c. 1600; ed. 1655)', DPhil. thesis, Oxford University, 1986. 


\section{Frances Dawbarn}

only an important player within the intricate patronage networks of his day, he was also intimately involved with the processes of change that characterized the attempts by the College of Physicians to establish itself as a "professional body" in early modern London. ${ }^{2}$

The paper takes as its starting point the problems associated with Moffet's election to the College of Physicians. Houliston observes that Moffet "had some initial difficulty in being recognized by the Royal College of Physicians", ${ }^{3}$ and Charles Webster notes that "his relations with the College of Physicians were never more than cool". ${ }^{4}$ As we shall see, these assessments differ from other views; they also invite a closer examination of Moffet's relations with the College.

In 1634, thirty years after the death of the author, Theodore Mayerne published his edition of Thomas Moffet's Insectorum sive minimorum animalium theatrum. In dedicating the work to Dr William Paddy, fellow member of the London College of Physicians, friend of Moffet, and royal physician, Mayerne described Moffet as "an eminent ornament of the Society of Physicians ... and renowned in most branches of science". 5 Anthony Wood's entry in Athenae Oxonienses (1691/2) informs us that Moffet "fell into very great practice within the city of his nativity [London] . . . and esteemed the famous ornament of the body of physicians". ${ }^{6}$ In 1878 William Munk repeated this information in the Roll of the Royal College of Physicians of London. ${ }^{7}$ In 1966 Allen Debus observed that Moffet was "a candidate of the Royal College of Physicians in December 1585, and was elected a fellow and censor of that body in 1588". ${ }^{\circ}$ And in 1985 Hugh Trevor-Roper described how Moffet "moved easily among the great ... He had a highly satisfactory career ... becoming ... a ... Fellow of the Royal College of Physicians and a very successful general practitioner".

These assessments, made after Moffet's death and spanning some 300 years, indicate that he not only established himself as a highly successful and sought-after practitioner of medicine in early modern London, but also enjoyed a distinguished career as a respected and eminent Fellow of the London College of Physicians. However, Charles Webster, Victor Houliston, and Thomas Moffet himself, suggest that his relationship with the College was, in fact, a troubled one.

\footnotetext{
${ }^{2}$ For a fuller discussion of the complex relationship between patronage and medical authority, see F Dawbarn, 'Conflict in early modern London: the College of Physicians and courtly patronage, 1580-1620', unpublished $\mathrm{PhD}$ dissertation, Lancaster University, 2000.

${ }^{3}$ Houliston, op. cit., note 1 above. Houliston's assessment of Moffet's difficulties with the College centres on his controversial Paracelsianism. This paper does not challenge this entirely sustainable view, but seeks to augment our understanding of the complexities of Moffet's career by examining his patronage relationships.

${ }^{4}$ Webster, 'Alchemical practitioners', op. cit., note 1 above, p. 329.
}

\footnotetext{
${ }^{5}$ Thomas Moffet, Insectorum sive minimorum animalium theatrum, ed. Theodore Turquet de Mayerne, London, 1634.

${ }^{6}$ Anthony Wood, Athenae Oxonienses, 2 vols, London, 1691/2, vol. 1, pp. 574-5. Wood also states that Moffet "... spent some time at this university ...". However, the Dictionary of National Biography (DNB), Oxford University Press, 1921-22, vol. 13, p. 548, suggests that this information is "erroneous".

${ }^{7}$ William Munk, The roll of the Royal College of Physicians of London, 1518-1700, London, The College, 1878, vol. 1, pp. 91-3.

${ }^{8}$ Debus, op. cit., note 1 above, p. 71 .

${ }^{9}$ Trevor-Roper, op. cit., note 1 above, p. 163.
} 


\section{New Light on Dr Thomas Moffet}

In July 1584 Moffet wrote a letter to the President of the London College of Physicians regarding his admission as a candidate for membership.

You can not be ignoraunt, what you and the rest of the College promised me at our last meeting, swearing by no lesse other than fayth, truth and credit that you were fully determynid to preferre me to that place as soone as any vpon any occasion were voide. What cause therefore may therebe, that $I$... should ... so contemptuously be vsed ... ${ }^{10}$

It is clear that this letter stands in contrast with other assessments. It suggests that the situation was far from satisfactory and that, even before his admission, significant tensions existed between Moffet and the College officers. In order better to understand these tensions we must consider his career as a member of the College in conjunction with his other important roles as client and patronage broker. Neglecting to do so gives the impression of an unproblematic relationship with his noble patrons, and marginalizes his considerable difficulties with both College and court. Close analysis of The Annals of the London College of Physicians serves to restore the balance by introducing us not only to Moffet's dealings with the College but also, importantly, to his patronage obligations.

\section{Thomas Moffet}

The second son of a London haberdasher, Thomas Moffet ${ }^{11}$ was not gently born. However, as a physician and natural philospher, his intellectual accomplishments attracted him to the highest courtly circles, and he spent most of his adult life in the company of kings, nobles, diplomats, and scholars. ${ }^{12}$

Moffet was educated at Trinity College, Cambridge, where he studied under the eminent Galenist and future President of the College of Physicians, John Caius. According to Anthony Wood, he also spent some time at Oxford. ${ }^{13}$ Moving from Galenist Cambridge, Moffet travelled abroad completing his medical studies at the University of Basle, where he obtained his MD, later to be incorporated at Cambridge. At Basle, known for its association with Paracelsus and its promotion of chemical cures, Moffet studied with the humanist iatrochemists Felix Platter and Theodor Zwinger. ${ }^{14}$ In 1578 he published his doctoral thesis De anodinis medicamentis theses in medicor. In it he "expressed his loyalty [to Paracelsus] so provocatively that the thesis was referred back to him and he was awarded the doctorate only after he had retracted his intemperate attacks on Galen and his Protestant champion Erastus". ${ }^{15}$

\footnotetext{
${ }^{10}$ Letter from Thomas Moffet to the President of the London College of Physicians, The Annals of the Royal College of Physicians of London, 23 July 1584, vol. 2, p. 27. Typescript translation of the early modern Annals, vol. 2, 1581-1608, held in the Royal College of Physicians' Library.

${ }^{11}$ The spelling of Moffet's name appears variously as Muffett, Moufett, Moffett. I adhere
}

throughout this paper to the spelling used in his Nobilis, transl. Heltzel and Hudson, op. cit., note 1 above.

${ }^{12}$ Houliston, and Helzel and Hudson provide the most comprehensive biographical details of Moffet.

${ }^{13}$ See Wood, op. cit., note 6 above.

${ }^{14}$ Debus, op. cit., note 1 above, p. 71.

${ }^{15}$ Trevor-Roper, op. cit., note 1 above, p. 163. 


\section{Frances Dawbarn}

From these heterodox beginnings we may trace Moffet's attraction to the intellectual circles in which he would move for the remainder of his relatively short life.

In England, Moffet's greatest patrons were Sir Philip Sidney, Robert Devereux, Earl of Essex, Sir Francis Walsingham, Lord Willoughby of Eresby, and Mary Herbert, Countess of Pembroke, sister of Philip Sidney. Among his associates abroad were the great astronomer and Paracelsian, Tycho Brahe, and Peder Sorensen (known as Petrus Severinus), also a Paracelsian and physician to Frederick II of Denmark, into whose circle Moffet was drawn whilst on a diplomatic mission to Denmark in $1582 .{ }^{16}$ From 1588 he was a Fellow of the London College of Physicians, and towards the end of his life he became Member of Parliament for Wilton in Wiltshire, "a borough controlled by Philip Sidney's brother-in-law, the Earl of Pembroke". ${ }^{17}$

To the Pembrokes' son, Sidney's nephew William Herbert, Moffet dedicated Nobilis, which was probably written in 1592, some six years after the death of Sidney after the battle of Zutphen. ${ }^{18}$ Moffet's elegiac and moving biography of his patron ranks with those of Fulke Greville, Angel Day, and Thomas Churchyard ${ }^{19}$ as being among the most important contemporary accounts of the life of one of the greatest Elizabethan literary figures. Moffet recalls Sidney's precocious appetite for learning, and tells us that "he pressed into the innermost penetralia of causes; and ... with [Dr John] Dee as teacher ... he learned chemistry, that starry science, rival to nature". ${ }^{20}$ This was an interest that was shared with equal enthusiasm by Philip's sister Mary, later Countess of Pembroke, who "gave an honourable yearly Pension to Dr. Mouffet", who had become her physician. ${ }^{21}$

From Nobilis we also learn that Moffet may have treated Sidney's wife, the former Frances Walsingham, for infertility. Indeed, Hugh Trevor-Roper notes that he was "physician to the avant-garde statesmen and courtiers of Queen Elizabeth-the supporters of the Earl of Leicester and a forward policy in Europe-Sir Francis Walsingham, Sir Philip Sidney, the Earl of Essex, Sir Francis Drake”. Interestingly, Trevor-Roper adds that "the Queen herself clung to established ways and Muffet died in 1604 , too soon to profit by the more liberal attitude of the next King". ${ }^{22}$

\footnotetext{
${ }^{16}$ See Jole Shackelford, 'Paracelsianism and patronage in early modern Denmark', in Bruce T Moran (ed.), Patronage and institutions: science, technology and medicine at the European court, 1500-1700, Woodbridge, Boydell Press, 1991, pp. 85-109.

${ }^{17}$ Hugh Trevor-Roper, 'The court physician and Paracelsianism', in V Nutton (ed.), Medicine at the courts of Europe, 1500-1837, London, Routledge, 1990, pp. 79-94, on p. 91.

${ }^{18}$ Moffet, Nobilis, transl. Heltzel and Hudson, op. cit., note 1 above.

${ }^{19}$ See Introduction to Moffet, Nobilis, transl. Heltzel and Hudson, op. cit., note 1 above, for a
}

\author{
discussion of the many contemporary \\ biographical eulogies of Philip Sidney. \\ ${ }^{20}$ Ibid., p. 75. \\ ${ }^{21}$ John Aubrey, Brief lives, ed. Oliver Lawson \\ Dick, London, Secker and Warburg, 1949, p. 139. \\ See also $D N B$, vol. 13 , p. 549 ; translators' \\ Introduction, Nobilis, op. cit., note 1 above, \\ p. xv; Margaret P Hannay, "How I these \\ studies prize": the Countess of Pembroke and \\ Elizabethan science', in L Hunter and S Hutton \\ (eds), Women, science and medicine 1500-1700: \\ mothers and sisters of the Royal Society, Stroud, \\ Sutton Publishing, 1997, pp. 108-21. \\ ${ }^{22}$ Trevor-Roper, op. cit., note 17 above, p. 91.
}




\section{New Light on Dr Thomas Moffet}

The "established ways" of the ageing Elizabeth left an intellectual as well as political vacuum at court, one that was increasingly filled away from the stifling atmosphere of Whitehall. Malcolm Smuts has suggested that the encouragement of diversity and change within Jacobean courtly circles did not radiate solely from a monarchical nucleus, but also from courts which existed independently of Whitehall. ${ }^{23}$ That such circles also existed in Elizabeth's reign is indicated by Walter Ralegh's interest in chemistry, which he shared with Henry Percy, the "wizard" ninth Earl of Northumberland. Through his friendship with Peter Turner and Timothy Bright, ${ }^{24}$ Moffet's name was also to be linked with this circle.

The existence of forward-looking alternatives to Whitehall, and indeed to the English universities which remained firm bastions of Galenism, was of particular significance for Moffet, who had already tasted intellectual excitement through his association with the University of Basle and the Danish court. Seeking not only to secure his personal status and fortune, but also to engage in the process of challenging the prevailing intellectual order, Moffet found a congenial home among members of the Sidney circle. His controversial (although subsequently moderated) doctoral thesis had already attracted attention, and in due course it was to be augmented by other works, including De venis mesaraicis obstructis ipsarumque ita affectarum curatione ..., which he dedicated to his friend Dr Thomas Penny and published in the same year as his doctoral thesis; De jure et praestantia chymicorum ... (1584), a work which takes the form of a debate, was dedicated to Severinus; Nosomantica Hippocratea ... in 1588, dedicated to his travelling companion in Denmark, the diplomat Lord Willoughby of Eresby, and in 1599 the Silkwormes and their flies, dedicated to Mary Herbert, Countess of Pembroke.

As Mario Biagioli has shown in the case of Galileo, intellectual patronage presented the client with an opportunity not only to engage in the important process of selffashioning, but also to transform the status of a philosophical world-view. Indeed, at a time when "hierarchies among disciplines ... did not represent simply ... a philosopher's view of a specific phenomenon and that person's ranking within a professional community, but the entire social status and identity of the person", ${ }^{25}$ Moffet grasped patronage opportunities that encouraged his broad perspective upon the physic he provided, which was integrated into a multi-dimensional world view. Like Galileo, the whole of Moffet's "status and being"26 was capable of being shaped by the intellectual milieu within certain receptive courtly settings. And, like the European courts of Frederick II of Denmark, Henri IV of France, Rudolf II of

\footnotetext{
${ }^{23}$ Malcolm Smuts, 'Cultural diversity and cultural change at the court of James I', Linda Levy Peck (ed.), The mental world of the Jacobean court, Cambridge University Press, 1991, pp. 99-112.

${ }^{24}$ Translators' Introduction, Moffet, Nobilis, transl. Heltzel and Hudson, op. cit., note 1 above, p. Xv.
}

\footnotetext{
${ }^{25}$ Mario Biagioli, Galileo, courtier: the practice of science in the culture of absolutism, Cambridge University Press, 1993, pp. 218-19.

${ }^{26}$ Galileo Galilei, Opera, cited in Biagioli, op. cit., note 25 above, p. 11 .
} 


\section{Frances Dawbarn}

Prague, and Maurice, Landgrave of Hessen-Kassel, the "avant-garde" courts of England, with which Moffet was increasingly associated, provided not only social promotion to the innovating individual, but also intellectual succour to new philosophies of nature. As we shall see below, certain allusions to his staunch Protestantism suggest that Moffet's confessional allegiance was closely allied to a natural philosophy which found sympathetic adherents at many of the Protestant princely courts of Europe. In 1582, having mixed with the elevated clients of just such courts, Thomas Moffet presented himself to the London College of Physicians as a candidate for the next vacant Fellowship.

\section{Thomas Moffet and the College of Physicians: Esteemed Colleague or Uncomfortable Bedfellow?}

Despite its statutory authority to monitor medical practice in London and seven miles around, the College of Physicians was forced to confront significant challenges from a multitude of informal and untrained medical providers. Its statutory powers to protect the king's subjects from the dangers of quacks and empirics was central to the promotion of learned Galenic physic, and to the position of the College as its guardian. Furthermore, in the years following its foundation in 1518, the College had attempted to define the unique and particular qualities that characterized the good physician by enlarging its letters patent to include the following words:

And forasmuch as the making of the said corporation is meritorious, and very good for the commonwealth of this our realm, it is therefore expedient and necessary to provide, That no person of the said body ... be suffered to exercise and practice physic, but only those persons who be profound, sad, and discreet, groundly learned, and deeply studied in physic. ${ }^{27}$

Thus the founders and their successors added considerable moral to statutory authority, and manners, bearing, and demeanour became as significant a mark of the physician as learning. ${ }^{28}$

The relationship of Thomas Moffet with his patrons and with the London College of Physicians provides an excellent vehicle by which to examine one particular problem in depth; namely the role of its members and Fellows as clients of noble patrons and as patronage brokers. It also stands as an example of the College's difficult position regarding an individual who not only "moved in the highest court circles", ${ }^{29}$ but also held heterodox views on physic. How were the Fellows to balance the undoubted honour Moffet's courtly connections reflected upon the College with

${ }^{27} 14 \& 15$ Henry VIII, c. 5 . The privileges of and authority of Physicians in London 1522-3.

${ }^{28}$ See Harold $\mathrm{J}$ Cook, The decline of the old medical regime in Stuart London, New York, Cornell Press, 1986; idem, 'Policing the health of London: the College of Physicians and the early Stuart monarchy', Soc. soc. Hist. Med., 1989, 2: 1-33; idem, 'Good advice and little medicine: the professional authority of early modern physicians', J. Br. Stud., 1994, 33: 1-31.

${ }^{29}$ Debus, op. cit., note 1 above, p. 71. 


\section{New Light on Dr Thomas Moffet}

his other more heterodox - not to say disreputable - associates and the dangerous ideas they shared? ${ }^{30}$ Like many patronage relationships, those in which Moffet was involved were elaborate and complex, their successful management requiring considerable skill and diplomacy. But, as we shall see, Moffet's loyalties were compromised by his triple role as client, broker, and Fellow of the College.

In $A$ history of the Royal College of Physicians of London, Sir George Clark notes that in 1584, when Moffet was seeking admission, the "status of candidate [had] created a reservoir of doctors ready for admission when vacancies occurred or when they had completed the four years of practice required before admission". ${ }^{31} \mathrm{He}$ also astutely observed that problems arose from the existence of this "reservoir"; the College was not only obliged to make "invidious" choices between candidates, but it was also confronted by "pressure from the influential friends of the candidate". ${ }^{32}$

Given that he came fully equipped with impressive academic credentials and courtly connections, the prima facie case for Moffet's immediate admission as a candidate would seem to have been unassailable. Yet the College hesitated, and admitted Dr Edward Dodding and Dr Thomas Randall to the candidacy ahead of him, although he had been assured of the next vacancy. ${ }^{33}$ The decision precipitated the following response, addressed to the President of the College, Dr Roger Giffard. ${ }^{34}$ Although it is undated, it is recorded as having been read out in the Comitia which met on 23 July 1584.

Mr. Dr. Giffard, Hearing but yet hardly beleeving that you are purposed to preferre certaine others before me in the Candidateshipps which are now of late fallen void: I thought it not amisse to send these few lines vnto you as expostulators of my right, if happely you were so vnrightly mynded against me. You can not be ignorant, what you and the rest of the College promised me at our last meeting, swearing by no lesse other than fayth, truth and credit that you were fully determynid to preferre me to that place as soone as any vpon any occasion were voide. What cause therefore may therebe, that I, which once was in suche favour shuold now so contemptuously be vsed: ... ${ }^{35}$

Continuing in angry vein at some length, Moffet reminded the President that he had visited the College "three yeares since" adding, perhaps unwisely, that he had also "visited 2 or 3 of them, [the candidates proposed in his place] being suche

\footnotetext{
${ }^{30}$ Houliston, op. cit., note 1 above, p. 32 . Houliston suggests that Moffet's relations with the College "evidently improved" as his courtly connections became more firmly established. However, as this paper shows, the complexities of Moffet's patronage obligations made the situation difficult.

${ }^{31}$ Sir George Clark, A history of the Royal College of Physicians of London, 3 vols, Oxford, Clarendon Press, 1964-72, vol. 1, p. 133. College procedures were extremely complex and subject to change and revision over time. The number of Fellows was altered from time to time, as was the
}

inclusion (or exclusion) of the royal physicians among their number. Clark remains the best source of information regarding such matters.

${ }^{32}$ Ibid.

${ }^{33}$ Clark, op. cit., note 31 above, vol. 1, p. 133, fn. 3. Dodding and Randall appear in Munk's Roll, but they seem to have been relatively undistinguished members of the College.

${ }^{34}$ Two Giffards served in the College: Roger, who was President from 1581-4, died in 1596/7, and John, who was admitted in 1589 and became President in 1628.

${ }^{35}$ Annals, op. cit., note 10 above, p. 27. 


\section{Frances Dawbarn}

manner of men, as I will not vouchsaffe to speak vnto: nor to bid them, god speede". So uncompromising a demonstration of his belief in his superiority to those the College had chosen instead of him, and the fact that Moffet had clearly taken the trouble to "vet" the candidates himself, cannot have furthered his cause. With an unmistakable allusion to the staunch Protestantism that characterized not only his personal beliefs but also his courtly connections, Moffet asks:

Doth any one feare least I stepping into your Society, will marre their musick and Jollity? If he be a papist ... I hate him with an vnfainid hatred because he is enemy to the truth of god and so consequently to our prince. But if he be a Protestant, god forbid I shoold do otherwise vnto him, then vnto the Ball of myne owne ey. ${ }^{36}$

Appealing to the College's sense of honour and its knowledge of the importance of preferment and prerogative, he asks that

God for his mercy sake, graunt that as in dignity you have the cheefest place so together you may excell in equity, whereby princes stand and all Colleges prosper ... But if for moony you allow a man and disalowe him againe, when you list: if you draw on your fellowe bretheren, with faire wordes as with baites and then having them on your hooke, pull the gutts and the lief out of their bellies surely well may you strengthen your selues with newe lawes new taxes and newe freends:

He continues with the striking, but enigmatic, observation, "But yet god in his Justice wil confound you and make the College of Phisitions more odious in London than it ever was in Rome." And finishes with:

You can not be ignorant of that saing in Plautus.

Est qui nos regit, atque gubernat, Deus:

Bene merenti, bene est, male merenti par erit, Cogita. $^{37}$

Your assured frende for ever if it please you. Tho. Muffet.

Moffet's mention of "moony", in extremely unflattering terms, is undoubtedly a reference to the fees candidates were obliged to pay during the years they spent waiting for a vacant Fellowship, and the "newe laws taxes and ... freends" a suggestion that certain benefits might be reaped from a steady income which had been created by the "reservoir" of doctors waiting in the wings. Indeed the entry in the Annals for 3 November 1581 records that "[w]ith regard to Muffett it was decided that within seven days he should give his pledge to the College that he would pay

\footnotetext{
${ }^{36}$ Ibid. A note in the translators' Introduction to Moffet, Nobilis, transl. Heltzel and Hudson, op. cit., note 1 above, states that at Cambridge, Moffet, who was a "very proper scholar, and very forward in religion", was driven from Caius College by Dr Thomas Legge, it is charged, on account of his anti-Catholic opinions.

${ }^{37}$ Annals, op. cit., note 10 above, pp. 26-7. Moffet is quoting from Plautus, The captives,
}

transl E F Watling, pp. 313-16. "There is surely a God above, who sees and hears all we do; / he will reward kindness with kindness, I am sure; and unkindness with its like." The story of The captives suggests that Moffet is reminding the College that he will one day become their "son". See http://www.san.beck. org/. I am grateful to Stephen Pumfrey for the reference to this website. 


\section{New Light on Dr Thomas Moffet}

the sum of eight pounds for the use of the College, in four equal amounts until he should be admitted a candidate." 38 In July 1583 Moffet's fees were still under discussion, ${ }^{39}$ and in November he was listed as owing the College $£ 6 .{ }^{40}$ Much to his chagrin, matters dragged on unresolved and when Drs Dodding and Randall were admitted in preference to him he penned his letter.

In view of the College's insistence that its moral authority was predicated not only upon its members' demonstration of learning, but also upon their gentlemanly behaviour, it is scarcely surprising that Moffet's abrasive defence of his religion, his suggestion that the Fellows were influenced by the size of a candidate's purse, and the fact that he was in financial debt to the College, drew from the Registrar the following observation:

The letter which Dr. Muffet had written to Dr. Giffard, the President, was read. Since its tone was not as courteous as it should be the Fellows were offended. Wherefore the Registrar was enjoined to have it written in the Annals for a permanent record. ${ }^{41}$

He also recorded that present in the Comitia that day were the newly elected Fellows Drs Dodding and Randall, whom Moffet had weighed in the professional balances and found wanting. Clearly he did not yet "esteeme the famous ornament of the body of physicians", ${ }^{2}$ nor it him, and, while some have noted Moffet's entry into the College in terms of high achievement, we have seen that it was with extremely controversial connections and credentials that Moffet first presented himself for the candidacy in 1581 . He was not admitted a Fellow until "the last day of February $1586 / 7 "{ }^{43}$

However, the intervening years had not been uneventful, and in 1585 , the year following his letter to the College, it was necessary for Moffet to respond to the serious accusation that he had caused the death of a certain "Mr. Beaumont" ${ }^{44} \mathrm{He}$ related the events, which had taken place "a yeare since", in a letter dated 20 July 1585, to Michael Hickes, private secretary to Robert Cecil, first Earl of Salisbury, and long-standing friend of Beaumont. ${ }^{45}$ It is the letter of an indignant and worried man. The extracts that follow are published here for the first time.

Mr. Hickes, notwithstanding [that] yow and Mr. Beaumont his sonnes, daughter, servants, and other friends, are most certainly p[er]suaded, (as ye ought to be) that the two spoonfulls of julep wch he tooke in his sickness from myne apothecaries, were of a drink most comfortable and restorative and (though I saye it) as comfortable [in] temper and cordiall in all respects as hath binne by any man devised: Nevertheless such is the malice of myne owne adversaries who by writing have chalenged a yeare since to defend their absurdities and ignourance, that

${ }^{38}$ Annals, 3 Nov. 1581, p. 4.

${ }^{39}$ Ibid, p. 20.

${ }^{40}$ Ibid, p. 22.

${ }^{41}$ Ibid, p. 26.

${ }^{42}$ Wood, op. cit., note 6 above, vol. 1 , pp. 574-5.

${ }^{43}$ Annals, op. cit., note 10 above, pp. 49-50.

${ }^{44}$ British Library Lansdowne MS. 107, ff. 22.

This was Nicholas Beaumont of Coleorton in

Leicestershire. The post-mortem is mentioned by
Alan G R Smith, Servant of the Cecils: the life of Sir Michael Hickes, 1543-1612, London, Cape, 1977, p.106. It is possible that this late-sixteenthcentury account is one of the earliest extant records of a post-mortem. See also, David Harley, 'Political post-mortems and morbid anatomy in seventeenth century England', Soc. Hist. Med., 1994, 7: 4-28, for a discussion of early post-mortems.

${ }^{45}$ Smith, ibid., p. 106. 


\section{Frances Dawbarn}

they cease not (as I am informed by D. Denny) ${ }^{46}$ wickedly and againe ... to report of [that] drinke, as the cause of Mr. Beaumont his death ... [C]hildren have drounk a gallon of ye drink, and eaten a pownd of [that] Electuary at severall times to their most happy restoring owt of consuming and long feuers: ... Yow and divers [others] can testify that if myselfe draunk not 2 spoonfull, but 2 bowles full of ye same drinks together: and yow yourselfe, Mrs Bexo (as I remember) and Mr. Beaumont his sonnes, and one of the [others] dranck a good quantity therof. Yow knowe and have felt the effect ... and therfore as manifest eyewitnesses are able to [and] willing to confuse the adversary and againe when I see on their part the malice hath no measure, and envey cannot be contayned in ye bondes of honest dealing: I [am] I say so confirmed and settled in mind by both those arguments that (God be praised therfore) I am nothing moved in my selfe, how much they seemd (as madd men) to be removed owt of them selves.

There follows a very detailed account of what may be one of the earliest descriptions of a post-mortem. The dead man's muscles were found to be:

spotted with yellowe black and blue spottes ... [the] lungs were very read, and swolen, and inflamed, and rotten in most places ... [the] ... harte was very faire and sound. His liver spotted with white and redd spottes all over, resembling the bitings of flease ... [The] kidneyes [were] faire, and att ye present time without stones. His gall little, and emptied. His guttes full of wind ... [The] quartered [peritoneum and omentum revealed] divers ulcers bredd within ... which had eaten assunder the skinne of the saide call [the omentum] ... and a store of ichorous [jaundiced] bloode ... about the guttes, and falling also into his coddes.

It was the "corrupt matter ... [contained within the ulcers which was] ... so sharpe that it almost fetcht of ye skinne from ye surgeons hands" which Moffet believed was the "cause of that extreme and continuall paine in his belly ... [and] the instrument of his death". Moffet had wished to examine the patient's brain but "his sonne seeing sufficient causes of his fathers death, would have us proceed no further, and so we ended". The letter closes with the following plea, which includes a further indication that Moffet shared his religious views with many of his patients and patrons:

Thus desiring you communicate this letter with Mr. Beaumont his sonnes, whose consent in religion lincketh unto me (no doubt) a consent of good will, and will p[er]suade the[m] to report ye truth of me: ... From Ipswich 20 of July 1585 your assured friend ... Tho: Moffet.

Although he gives no details of the ingredients of the julep or the electuary, Moffet is at pains to point out, vehemently and several times, the harmlessness of the substances, and considers himself vindicated by the results of the post-mortem. Fortunately, it was attended by Mr. Beaumont's son who was entreated by Moffet, via Hickes, to clear his name. Not only had Moffet's enemies accused him of a serious breach of professional conduct, they had done so at a time when he was seeking the candidacy of the London College of Physicians. This episode, and his

\footnotetext{
${ }^{46}$ No D(octor) Denny appears in the Annals, or in Munk, for this period. Perhaps Moffet refers to his friend Dr William Penny.
} 
known support of Paracelsian medical doctrine, surely contributed to the delay. The career of Thomas Moffet, the so-called "ornament of the Society of Physicians" begins to look less straightforward.

1588, the year after his admission as Fellow, marked Moffet's only year as a censor. Serving for a single year was unusual and, unlike many other Fellows who served as censors, Moffet was never to hold any other College office. This suggests either that his election as censor had not been an altogether happy choice, or, for reasons that will be discussed below, his view of the College, and the importance of holding office within it, was more ambivalent than one would expect of an "ornament".

In the same year Moffet's Nosomantica Hippocratea was published in Frankfurt. Compared with his earlier works, this "digest" ${ }^{\text {"47 }}$ is much more moderate in tone. To quote Debus, "here again we may note one of the hallmarks of Paracelsianism: if any of the Greek physicians were to be studied, it should be Hippocrates and not Galen" ${ }^{48}$ Despite the now more moderate Moffet, who had "learned" 49 to appreciate the works of the ancient Greek physicians, the names of the other individuals admitted that day indicate that the arrival of doctors who had either studied for, or completed, their MD in foreign universities heralded changes that alarmed the College. Elected with Moffet was Dr Henry Atkins, a doctor of medicine from the University of Nantes. Atkins, like Moffet, would attend the second Earl of Essex as his physician. ${ }^{50} \mathrm{He}$ was held "high in the esteem and confidence of James I", having been entrusted with the responsibility of bringing the infant Prince Charles from Scotland in $1604 .{ }^{51}$ During his Presidency of the College, the 1618 London Pharmacopoeia appeared, in which chemical remedies were included for the first time. ${ }^{52}$ Dr Thomas D'Oylie, like Moffet an MD from the University of Basle, was also elected that day, as were Drs Farmery and Osborne, who had both taken their medical degrees at the University of Leyden. Dr George Turner from a university of Venice was also admitted. ${ }^{53}$

The University of Basle (and indeed Leyden) was known to take an active interest in and to support chemical or Paracelsian medicine, but the name of Moffet, more than the other Fellows elected on the last day of February 1586/7, was associated with unorthodox physic. In 1586/7 the College was still fourteen years away from relaxing its prohibition against alchemy, ${ }^{54}$ and in 1585 , the year after Moffet's letter, the College had toughened the statutes regarding the admission of foreign doctors, or Englishmen who had taken their degrees at foreign universities. ${ }^{55}$ There was a

${ }^{47}$ Debus, op. cit., note 1 above, p. 71.

${ }^{48}$ Ibid.

${ }^{49}$ Ibid.

${ }^{50}$ Atkins was to be replaced by Dr Marbeck, the College Registrar, when sea-sickness forced him to abandon his service to the Earl on the 1597 naval expedition.

${ }^{51}$ Munk, op. cit., note 7 above, p. 94.

${ }_{52}$ Not to be confused with the proposed versions, of 1585 and 1589 , which were not published.

\footnotetext{
${ }^{53}$ Munk says his degree was taken "in some foreign university" but notes that "Venet" is against his name in the College list for 1597. Munk, op. cit., note 7 above, p. 90.

${ }^{54}$ Clark, op. cit, note 31 above, p. 179.

${ }^{55}$ The Annals entry dated 23 Oct. 1585, vol. 2 , p. 35 , is concerned with those who "have left their universities before the end of their course to go abroad where ... in a shorter time and with less expense they take the doctorate degree." In order to ensure that those who
} 


\section{Frances Dawbarn}

considerable fear of handing those influenced by heterodox teaching too easy a route into the College.

By 1586, the year of Philip Sidney's death, Moffet included Anne Seymour (widow of the Protector) among his patients. He attended her deathbed, and he and Dr Penny attested her will. ${ }^{56}$ However, Moffet's name was linked not only with Penny, but also with Peter Turner and Timothy Bright; all four had studied medicine together at Cambridge under John Caius. ${ }^{57}$ Through his association with these colleagues, we find the links between Moffet and the family and friends of Philip Sidney. Bright was a client of Francis Walsingham, in whose house he and Philip Sidney had sheltered in Paris during the St Bartholomew's Day Massacre. In 1582 Walsingham (Sidney's father-in-law), sent Moffet and Peregrine Bertie, later Lord Willoughby of Eresby, on a diplomatic mission to invest the Danish King, Frederick II, with the order of the garter. Walsingham's relationship with the College was characterized by his persistent protection of "quacks and empirics", and it will be remembered that the Earl of Essex would marry Philip Sidney's widow, Frances Walsingham, thus further strengthening the alliance between the two families, and Moffet's links with them.

Moffet's other friend from his Cambridge days, Peter Turner, is known to have taken a keen interest in chemical medicines and would later collaborate with Walter Ralegh and probably Henry Percy, ninth Earl of Northumberland (the brother-inlaw of Moffet's patron, the Earl of Essex), in their study of the chemistry of metals, made in the Tower during their imprisonment. ${ }^{58}$ Turner's entry into the College of Physicians had been stormy, and the letters patent granting his licence in 1582, when Moffet was also at loggerheads with the College, include the cautionary words that "[i]n his practice he is to call in no quacks, no ignorant men and above [all] no-one whom he knows has not been admitted to the College to practise". 59

Eventual Fellowship did not put an end to Moffet's difficulties. Indeed it exacerbated an already tense situation, in which he was now obliged to juggle his new roles as patronage broker and College Fellow. The second section of this paper traces Moffet's career from 1586/7, the year of his admission as Fellow, and examines his relationship with the Earl of Essex, Leonard Poe, and the College of Physicians, and his controversial opinion of the "quack" Roger Powell.

\footnotetext{
have been "created Doctor at home ... should receive preferential treatment [and] to overcome this evil ... any person who is admitted in this kingdom ... at the time of his admission ... he shall pay the President, Registrar and the College officers, three times the fees paid by those who have been created doctors in our own universities."

${ }^{56}$ July $1586 . D N B$, vol. 13 , p. 549.

${ }^{57}$ Ibid., p. 548.

${ }^{58}$ Webster, op. cit., note 1 above, p. 307. See also G R Batho, "The library of the "Wizard"
}

Earl: Henry Percy Ninth Earl of Northumberland (1564-1632)', The Library, 5th Series, March 1960, 15 (1): 246-61; John William Shirley, 'The scientific experiments of Sir Walter Ralegh, the Wizard Earl and the three magi in the Tower 1603-1617', Ambix, 1945-51, 6: 52-66. Henry Percy was married to Dorothy Devereux, Robert's sister.

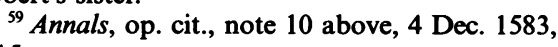
p. 15. 


\section{Thomas Moffet, Patronage Broker and Fellow of the London College of Physicians: A Conflict of Interest}

On 25 June 1585, the College Fellows met in Comitia, where it was "proposed to publish one reliable and uniform pharmacopoeia". However, it was decided to postpone discussion until the Fellows could give more time to so important an undertaking. ${ }^{60}$ No more was heard of the project until 10 October 1589, when "[i]t was proposed, discussed and resolved to compile and publish one uniform Pharmacopoeia or Dispensary of prescriptions ... [The task] was divided into various groups each of which was assigned as a special duty to the individual Fellows". To Thomas Moffet, and his colleagues Drs Langton and Johnson, fell the responsibility of preparing the section on 'Extracts, Salts [and] Metallic Chemicals' ${ }^{61}$ By 1589, the date of the proposed pharmacopoeia, Moffet had been a Fellow of the College for two years, and had served his (only) year as censor. Giving him the responsibility for the section on chemicals perhaps seems an obvious choice, and suggests that the College was willing to acknowledge Moffet's expertise in the field of iatrochemistry. This suggests that earlier difficulties had to some extent eased. Certainly there is no mention in the Annals of conflict between the years 1586/7 and 1589 .

However, by the time of the College elections, at Michaelmas 1589, Moffet's name was linked with that of the "empiric" Leonard Poe, who, although he made his first appearance before the College in December 1589, had undoubtedly come to their attention some time before that date. ${ }^{62}$ It is possible that his connection with Poe was a significant factor in the decision not to re-elect Moffet to the office of censor.

The features of Poe's case, particularly in its early stages, are similar in many respects to others that the College was obliged to consider at almost every meeting of the Comitia. Indeed, if one were to search the Annals for a case in which most of the elements which characterized the College's problems with "quacks" and "empirics" were represented, the first few entries dealing with the case of Leonard Poe could not better serve the purpose.

Upon examination the College assessed Poe as "completely unlearned and ignorant of medicine in every respect". However, this opinion is recorded with the observation that "because of the intervention of Mr. North and that most noble man the Earl of Essex on his behalf, he was excused the payment of all fines for his previous practice", ${ }^{63}$ which, by Poe's own confession, had been going on for two years. ${ }^{64}$ By 18 May 1590 the College established that Leonard Poe was a "deacon of Lincoln", in which case he may well have been in possession of a diocesan licence to practise,

\footnotetext{
${ }^{60}$ Ibid., p. 34.

${ }^{61}$ Ibid., 10 Oct. 1589 , p. 60.

${ }^{62}$ It is not unusual to find individuals mentioned as a source of trouble several months or even years before they make a first appearance before the Comitia. This was usually because they refused to appear when summoned. Roger

Powell, to be discussed below, is a case in point.
} 
which the College was not obliged to recognize in London. However, on this occasion Poe appeared, seeking

a licence to practice in the French disease, in fevers and in rheumatism. He was examined and found to be a completely ignorant man. For this reason he was refused a licence. But however at the instance and petition of certain people his previous illegal practice was overlooked and the fine was remitted on condition that he did not practise any part of medicine in the future. ${ }^{65}$

We may infer from the previous entry that one "certain person" was the Earl of Essex, and that another was "Mr. North", of whom nothing more is known. However, Poe's appearance before the College with the very specific intention of acquiring a limited licence - one entitling him to practice "in the French disease"-suggests that, in the five months between his two appearances before the Comitia, he had made contact with someone who was privy to the inner workings of the College, and who had recommended a change of approach.

As an "external" ailment, the French disease was deemed to be within the competence of surgeons, and within the scope of the limited licence issued to them by the College of Physicians. The suggestion may have been made to Poe that, although he had twice been examined by the College, and on both occasions found to be inadequate, a case might be put forward for a limited licence, such as those issued to surgeons. These usually came with the proviso that the practitioner confine himself to the treatment of certain specific, named, maladies, and that in other or difficult cases he must call in a Fellow of the College to assist. It is highly unlikely that the Earl of Essex would have known of the existence of such a licence, but inconceivable that his physician, Thomas Moffet, who was also a Fellow of the College, did not. In his capacity as Poe's patronage broker, Moffet may have suggested the limited licence as a compromise. Indeed, we know that Moffet wrote to the President of the College, promoting Poe's case and assuring him of his competence. ${ }^{66}$ And on 20 May 1590, the Earl of Essex wrote a letter to the President of the College of Physicians in which he made it abundantly clear that Moffet had acted as an agent in the case of Leonard Poe. ${ }^{67}$

The Annals tell us that "[t]he Comitia [of 30 June 1590] was held in Dr. Muffett's house after a splendid feast ... [Later] the letter from the Earl of Essex on behalf of Leonard Poe was read" ${ }^{68}$ After the usual greetings, the Earl explained that he had entertained not long ago ... Mr. Po to be one of my phisitions, since which Time, I heare that he hath been molested and often called into question by you for his privat practising vpon his freends, and some matters (which have been vntruly suggested) laid to his charge. I

${ }^{65}$ Ibid., p. 66.

${ }^{66}$ Annals, op. cit., note 10 above, pp. 66-7.

${ }^{67}$ Houliston, op. cit., note 1 above, p. 42. Houliston's observation that "Essex continued to press, unsuccessfully, for Poe's acceptance for years afterwards" does not take into account the fact that, following Essex's fall, it was necessary for Poe to seek new patronage. The fact that the disgraced Earl was replaced by Poe's ever- growing "stable" of noble patrons is an indication that Moffet's role had been absolutely central in laying the all-important foundations of Poe's career. Poe's later bid for acceptance by the College, supported by many members of the Jacobean court, and eventually James I himself was, of course, unassailable.

${ }^{68}$ Annals, op. cit., note 10 above p. 66. 


\section{New Light on Dr Thomas Moffet}

understand that he can and hath discharge himself by very good proof as also that his sufficiency, for the cures of diuers diseases hath anie waies appeared, by soondrie good testimonies. These are therefore very earnestly to praie yow, that you will not only cease to trooble him hereafter, for emploieing his skill and trauell to the benefit and good of his freendes, who have a particular desire to deale with him: But also to graunt him suche Toleration: as yow haue in like cases geven to some of lesse experience and desert, and I shall accompt my self much beholding to yow for the same.

It seems that the Earl considered the College's statutory powers to examine prospective licentiates to be a form of "molestation", and certainly an unnecessary and unwelcome intrusion into Poe's right to practice "vpon his freends", who were prepared to provide "very good proof ... of his sufficiency". This was a familiar refrain among those who sought to justify their illicit or illegal practice. Nevertheless, Essex's remark that Poe practised only for "the benefit and good of his freends, who have a particular desire to deale with him", may hold the key to the reason for Poe's success. The "French disease" was known to be rife within courtly circles; indeed it was widely rumoured that the Earl suffered from it. ${ }^{69}$ If Poe had some particular skill in its cure, Essex and "his freends" no doubt wished to avail themselves of it. The letter continues by delivering an embarrassingly honest account of Moffet's role in the business. Reminding the President of Moffet's letter of recommendation, it places him in an acutely difficult position vis-à-vis the College.

I am perswaded that my phisition Mr. Dr. Muffet, is so well acqauinted with him, as his information of his sufficiency (wherewith he hath already by his letters acquainted Mr. President) yow will graunt him this curtesie for my sake. Thus I commit you to god. From the Court the 20 of Maie 1590 . Your verie loving freend R. Essex. ${ }^{70}$

Through his actions as patronage broker, Moffet had not only declared an interest in the career of Leonard Poe, and his opinion of his "sufficiency" as a physician, but had also passed his written opinion on to the President, something which the Earl, not unreasonably, thought might influence events in Poe's favour. Moffet's actions as patronage broker to Poe, and client of the Earl, thus compromised his allegiance to the College and caused embarrassment not only to his patron, but also to the President and Fellows of the College of Physicians.

A swift reply was sent to the Earl from the College in which pains were taken to remind him that the "wholsome laws of this Realme ... [existed] for the preservation of her Maiesties subiects". Essex was also assured that no molestation had taken place but merely "our ordinary examinations wherein in very truth [Poe was found] ... vtterly ignorant and vnfurnished ... in all partes of Physick ... as vpon our credit we never remember so weak a man to have appeared before us". Regarding Moffet's role in the affair, the President acknowledged that

in respect of his dutie to your Lord [he] had before indeed something delt with vs in [Poe's] behalf by letter: Yet being present at his examination and hearing his unexpected weakness

\footnotetext{
${ }^{69}$ Robert Lacey, Robert, Earl of Essex: an Elizabethan Icarus, London, Weidenfeld and Nicolson, 1971.
}

\footnotetext{
${ }^{70}$ Annals, op. cit., note 10 above, pp. 66-7. A letter from the Earl of Essex to the President of the College of Physicians, 25 June 1590.
} 


\section{Frances Dawbarn}

in so meane matters as were propounded vnto him: was very much abashed and sorie, that he had been woon to deale in so bad a matter. ${ }^{71}$

Under the circumstances, this was a generous explanation, but of course it was in the interest of the College to present a united front to the Earl. Given the uneasy relationship between it and other courtly patrons who were willing to protect physicians the College considered unsuitable, revealing the existence of internal disagreement might serve further to undermine its authority.

Can we ascertain Moffet's true opinion of Poe, and how are we to understand his actions, caught as he was between his duty to his patron and his allegiance to the College? Almost certainly he owed nothing to Poe (although he may have perceived a way of enhancing his own position by assisting him), and he should have had no difficulty in assessing Poe as the ignorant man the College later found him to be. Despite the President's (diplomatic) insistence that Moffet had been taken by surprise by Poe's "unexpected weakness", it is very unlikely that, in his capacity as patronage broker, Moffet would not have made his own assessment of Poe before submitting a letter of recommendation to the College.

The role of broker was potentially an extremely powerful one, although, as Moffet surely knew, not free from risk. Why did he take such a risk on behalf of Poe, an individual who ranked relatively low in the hierarchy of patronage within the Essex courtly circle? One explanation might be that, whilst Poe was indeed as ignorant as the College declared him to be, he had nevertheless hit upon an apparently successful treatment for the "French disease". ${ }^{72}$ An anonymous contemporary verse shows that his clients were drawn from among the highest ranks of the aristocracy. Resorting to vulgar double entendre, the verse describes the amorous exploits of Robert Cecil, first Earl of Salisbury (whose deathbed Poe would attend in 1612), and suggests that he too suffered from the French disease, but that Poe was unable to cure him.

Twixt Suffolk and Walsingham he often did journey

To tilt in the one and the other to tourney

In which encounters he got such a blow

He could not be cured by Atkins or Poe. ${ }^{73}$

If Poe did indeed treat the "French disease" (and usually with more success than he had with Cecil), Moffet stood to gain considerably in the Earl's estimation. He would be known as the client who had fulfilled his obligation to his patron by introducing him to a healer who was capable of providing an urgently needed cure. This placed Moffet in the advantageous position of agent in the provision of the greatest patronage gift that it was possible for a physician to give; cure, good health, and prolonged life. His agency was certain to be noticed by other highly placed patrons.

\footnotetext{
${ }^{71}$ Ibid., pp. 67-8. I cannot agree with Houliston's interpretation, that these letters and events were not used to embarrass the "abashed and sorie" Moffet. Houliston, op. cit., note 1 above, p. 41.

${ }^{72}$ For an excellent recent discussion of the "French disease", see Jon Arrizabalaga, John
}

\footnotetext{
Henderson and Roger French, The great pox: the French disease in Renaissance Europe, Yale University Press, 1997.

${ }^{73}$ Lawrence Stone, Family and fortune: studies in aristocratic finance in the sixteenth and seventeenth centuries, Oxford, Clarendon Press, 1973 , p. 52.
} 


\section{New Light on Dr Thomas Moffet}

We cannot, of course, discount the possibility that Moffet viewed the matter as disposed around the relative strength of his loyalty, duty, and commitment to two rival sources of authority: the College's and the Earl's. Apparently willing to risk compromising his position in the College, Moffet had decided in favour of the Earl. The consequences were to be far-reaching for all concerned. Although he alone cannot be held responsible for initiating the College's twenty-year struggle with Poe, Moffet's role should not be underestimated. ${ }^{74}$ As patronage broker he was the initial means of access between Poe and the Earl; without his agency, Poe's career among the aristocracy would have been extremely difficult, if not impossible. Direct access to a prospective patron being out of the question, Poe certainly would have been obliged to find an alternative route, although of necessity this would have been via another equally influential broker.

The role of Thomas Moffet as broker/client to the Earl of Essex illustrates that patronage was to remain an important determinant in the fortunes of the London College of Physicians as it struggled to assert its independence as a moral and statutory authority. This was, of course, to be challenged time and again, but the appearance of Roger Powell, in 1591, was to connect Moffet's name once more with that of a "remarkable and well-known impostor". 75

[On 3 September 1591] Roger Powell appeared on a charge of having fixed bills to the walls of houses and boasting in public of his cures and special experience in medicine: after his examination he confessed that he was a completely illiterate and unlearned man but that his experience in medicine was very long and very remarkable. He declared that he had practised medicine in this city for a long time and had cured many suffering from dangerous diseases. ${ }^{76}$

Although Moffet's name was not mentioned at this stage, the ingredients for future problems were already present: an ignorant man claimed long and remarkable medical experience whilst practising without a licence, and boasted publicly about his successes. Powell and his wife, who practised with him, had been difficult to bring to book, both having managed to evade the College's attempts to prosecute them for a considerable length of time. However, on 10 January 1594, Roger Powell appeared again, armed with letters of protection. On this occasion Moffet offered his opinion "on the quack" and it was carefully recorded in the Annals. A prominent note, "Dr. Mouffet's judgement on an empiric" in the margin makes it impossible to miss. The entry reads:

Powell appeared and showed a letter from Lord Herbert sent by the Commissioners in the Queen's name in which the Queen emphasized his poverty and success in medical diagnosis. In support of his case he produced a letter from Sir Charles Morison who had suffered from a swelling in the thigh: he had previously paid a large sum of money for its cure but in vain: he (Powell) had however in very truth restored him to health. Dr. Muffett in wonder at the affair asserted that diseases were cured not by speeches and letters but by experience. ${ }^{77}$

\footnotetext{
${ }^{74}$ Poe's case is recorded in the Annals, op. cit., note 10 above. It ran from May 1590 to July 1609.
}

${ }^{75}$ Ibid., 30 Sept. 1594, p. 89.

${ }^{76}$ Ibid., 3 Sept. 1591 , p. 73.

${ }^{77}$ Ibid., 10 Jan. 1594, p. 91. 


\section{Frances Dawbarn}

The Registrar also noted that Powell was excused imprisonment "out of respect to the Earl of Derby (to whom he was related)". ${ }^{78}$ No mention was made of the Queen's intervention, or the fact that she apparently supported the illegal practice of a "quack" and "impostor", from whom the College was authorized to protect her subjects; patronage at this level was indeed unassailable. However, Moffet's view was clearly considered worthy of mention, and doubtless served to confirm the Fellows' long-held opinion of him as a source of trouble. This may have seemed particularly so at the meeting of the Comitia held on 10 January 1594, to which Powell had brought his letters of protection, and at which Moffet's more notorious protégé, Leonard Poe, was also present to answer further accusations.

Moffet's rejection of the classical canons of Galenic literature, and the declamatory methods by which it was taught in the universities, should not, in the light of his publications and his courtly associations, have surprised the Fellows. However, his opinion of Powell, which emphasizes his practical ability as a physician, invites a re-assessment of his relationship with, and his opinion of, Leonard Poe. Despite agreeing with the College's view of Poe, patronage obligations (and a keen eye for an opportunity for self-promotion) encouraged Moffet to offer his support. However, we cannot discount the likelihood that Poe actually possessed a considerable practical ability, if not to cure the "French disease" then to alleviate some of its more distressing symptoms. Such an ability, Moffet believed, had nothing whatsoever to do with "speech and letters", but much to do with long experience.

Certain important clues, which assist in shedding more light upon both the nature of clientage and Moffet's relationship with the College of Physicians, have emerged from this view of his career. Of particular interest is the fact that he served only once as censor, and was never again to hold that or any other College office. I suggested above that, owing to his support of the "empirics" Poe and Powell, Moffet was passed over for re-election as censor. Whilst this may indeed have been a factor in the College's view of Moffet's suitability to stand in judgement upon those whose medical provision entered the realm of the heterodox, it also invites a consideration of his own view of the matter.

As we know, Moffet moved in the highest court circles, and the names of those to whom he dedicated his intellectual gifts show that he was an actively supported member of courts which provided a stimulating alternative to the oppressive and stale world of Whitehall, and also to the universities. As such, he was a highly valued client, actively engaged in the on-going process of an important patronage relationship, and obliged regularly to provide his patrons with the gifts which reaffirmed that he was worthy of continued support. First and foremost a natural philosopher, the gifts Moffet offered his patrons were of an intellectual nature; his function as a physician was secondary to his function as a philosopher. Thus his Fellowship of the College may be seen as less important than his status as a courtly client. Re-election as censor, or election to any College office, was perhaps of little significance to Moffet, who may not even have indicated an interest in such positions.

The indignation apparent in every line of Moffet's letter of 1585 manifestly issues

${ }^{78}$ Ibid. 
from the pen of a highly placed courtier who considers himself ill-used by his social and intellectual inferiors; it is not the indignation of an individual eagerly seeking professional recognition, or indeed the confirmation of his professional credentials. However, the letters sent to the College on behalf of Leonard Poe express precisely those ambitions and serve to illustrate the reason for the apparently contradictory co-existence within the same household of Poe, an alleged quack, and Moffet, the respected and internationally known natural philosopher. Clients supplied their patrons with very different services, and Poe's particular talent lay in his practical ability to provide a much-needed cure for the French disease. While it might be a greatly appreciated gift, and (as the persistence of Essex's attempts to win over the College, and Moffet's attempts to assist him indicate) an urgently needed one, it did not rank as highly as Moffet's intellectual gift. Within the Essex household, Leonard Poe, not Thomas Moffet, fulfilled the simple role of practical provider of physic, and apparently with enough success to win the support of the many other courtly patrons who came to his aid in his prolonged struggle with the College. However, as a natural philosopher, Moffet was of a higher status, which explains why, in assessing the risks involved in his tripartite dealings with Poe, the College, and Essex, he placed his obligation to the Earl above all others. Fulfilling his patronage obligations by attempting to secure the College's approval of Poe's medical practice was an action which exacerbated an already tense relationship. Moffet's association with heterodox physic provided the College with sufficient reason to attempt to exclude him from the Fellowship, and his later tendency to support individuals like Poe and Powell caused the Fellows to distrust him; indeed their nervousness is indicated by the Registrar's marginalia in the Powell case. Nevertheless, his association with prominent courtiers made his presence among their number desirable; managing such a dilemma was problematic for all concerned.

The Annals of the College of Physicians are an extremely valuable source of primary evidence although not, of course, a neutral one. Those who recorded its business represented themselves as the élite among London's medical providers, and had much to protect and to promote. However, in assessing Moffet's association with the College, patronage brokerage has emerged as a factor which not only affected the relationship between the College and one of its Fellows, but which also challenged its independent powers of prosecution. The Moffet case provides considerable detail, and places him in an intriguing and compromising triple role.

We have seen that two medical clients might occupy prominent positions within the same aristocratic household, each providing a widely differing, but nevertheless valued service. That their positions, relative not only to their patron, but also to each other, might lead to significant tensions in the fulfilment of patronage obligations is indicative of how they perceived the importance of securing the approval of the London College of Physicians. For Moffet, the natural philosopher, this was of secondary importance; for Poe, curer of the French disease, it was an irritating necessity which whetted an appetite for advancement scarcely paralleled in the history of the early modern College. ${ }^{79}$

\footnotetext{
${ }^{79}$ See Poe's case in the Annals, op. cit., note 10 above, and Dawbarn, op. cit., note 2 above.
} 


\section{Frances Dawbarn}

Importantly, Moffet's case reminds us that the College Fellows were not independent professional practitioners, but deeply reliant upon, and indebted to, courtly patrons for their professional existence. However, we see that in Moffet's case this left him very little room for manoeuvre. The complexities of his triple roles, as physician, client, and patronage broker, led to conflict and divided loyalties and has invited a re-assessment of his relationship with the College of Physicians. 